\title{
Relationship between Career Anchors and Organizational Commitment among Faculty Members
}

\author{
Dr. Ghalavandi, Hassan \\ Assistant professor, School of Literature and Human Sciences, \\ University of Urmia, Iran \\ E-mail: Galavandi@gamil.com \\ Dr Arbabisarjou, Azizollah, $\mathrm{PhD}$
}

Lecturer \& Faculty member of Zahedan University of Medical Sciences, Zahedan, Iran

E-mail: Arbabisarjou2007@gmail.com

Dr.Yarmohammadzadeh, Peyman

Assisstant professor, Azarbayjan University of Trabiat Moallem, Tabriz, Iran

E-mail: dr.peyman.ymz@gmail.co

Soltanzadeh, Vahid

Master student on Educational Administration

University of Urmia, Iran

E-mail: vahid.soltanzadeh@gmail.com

Iman, Solmaz, M.A

Educational Administration

University of Urmia, Iran

E-mail: Iman@gmail.com

Sokooti, Narges

Master student on Educational Administration, University of Urmia, Iran

E-mail: narges.sokooti@gmail.com

Received: August 15

Accepted: September 20

Published: February 1, 2012

doi:10.5296/jse.v2i1.1439
URL: http://dx.doi.org/10.5296/jse.v2i1.1439 


\section{Abstract}

Purpose-the purpose of this study is to examine the relationship between career anchors and organizational commitment among faculty members at the University of Urmia.

Design/methodology/approach- the empirical analysis is based on a sample of 70 faculty members of University of Urmia. The data were gathered through two standard questionnaires of career anchors according to Schein model and of organizational commitment according to Meyer and Allen model.

Findings- findings from this study indicate that there is a positive significant relationship between career anchor components and organizational commitment components and also technical functional competence, general managerial competence, autonomy- independence, pure challenge and life style are significant predicators' of organizational commitment.

Practical implications- career anchors are based on this logic that relatin between individuals career orientations and workplace leads to job satisfaction, high commitment and performance while lack of relation leads to dissatisfaction and turnover.

Originality, value- This paper presents original estimates of relationship between career anchors and organizational commitment with a sample of faculty members.

Keywords: Career anchors, Organizational commitment, Faculty members, University 


\section{Introduction}

In modern world empowerment, economic power and welfare of every largely depend on optimal using of opportunities, industries and especially human forces, Quality and skilled human resource appears to have a vital role in the development and progress of one country. Although labor, capital and land were main factors of production in the past, today technological changes, human forces and increasing productivity have been important factors in development and expansion (Sardary, 2000; Mirkamal, 2004; Nasarabadi et al. 2009). it is obvious that higher education offer opportunities for human growth throughout that world. The importance of universities as a key part of educational system is the recognition that there are large and diverse sets of public and private educational institutions which affect workforce and therefore development of every country (Ashwin, 2006; Romphel, 2006) lick (2002) suggested that university should constantly and effectively reconstruct itself in response to environmental necessities to ensure its effectiveness and survivance. specifically faculty members should have received much more attention since they have a momentous duty of breeding the future work force (Ghalavandi, 2010). At the core of the career anchor theory, which was developed by Edgar Schein(1978), is the concept that career anchor widely applied to all levels of employees. The most current implication of career anchor implies career development. In some cases career anchor refer to a job or career which requires high level of training and education. In other cases the term career anchor denotes a long term commitment with broad psychological investment in a career or organization(Abbaspour, 2008; Ghalavandi et al. 2010) Individuals whose career development path permits the integration of personal needs, organization needs and the requirements of the job are more committed to the organization (Oreyzi samani, 2009). Organizational commitment defines as a psychic attachment to the organization. Organizational commitment manifest in three understanding: 1-having faith in organization and accepting its goals and values 2-being inclined to strive for organization 3-wishing for remaining as a member of on organization (Ghafouri \& Golparvar, 2010).

\section{Theorectial Framework}

Some people are passive spectators in their life stage while others are active actors. Similarly in career path some individuals are more orientated toward their own skills and what they can contribute, while other individual are more inclined to be aware of the limitations of their role in the organization(Schein, 1996). Career path is a motivator for individuals to self management in their careers. Moreover those who are actively participating in their jobs can successfully achieve their goals (Verbruggens \& Sels, 2007). Career success requires great deal of information and endeavor that ensure success (Danzigeretal et al, 2008)

Career path represents a chain of career related experiences which individual acquires during time. The concept of career anchor as a balance between the individuals and organizations could be analyze from both external career includes all careers and the successes that individual promote through them, while internal career includes orientations, values, perception and effective reactions to job experiences that could have significant outcomes for staff's satisfaction, commitment, performance and retention in the organization. one of the 
crucial components of internal career is employee's orientation toward career anchors. Schein defines career anchor as an individual's self concept which is composed of three elements: 1self perceived talents and abilities 2-self perceived motives and needs 3-self perceived attitudes and values (Abbaspour, 2008). The first two elements are based on actual experiences in work settings while the third element is based on actual encounters with norms and values of the work and social circumstances (Danziger \& Valency, 2005). Schein (1990) after longitudinal study of a group of MBA graduates at the Massachusetts Institute of Technology (MIT) and developing career anchor concept, identified eight

\section{Career Anchors}

\subsection{Technical/ Functional Competence}

Individuals with high level of technical/ functional competence probably their occupational choice linking directly to technical/ functional content. These individuals usually avoid from decisions and paths which lead to managerial jobs and attempt to remain in their interested technical grounds.

\subsection{General Managerial Competence}

There are individuals who are motivated and inclined in managing others and their work experiences convinced them that they have necessary talents and abilities to reach managerial posts and they seek management posts whit high responsibility.

\subsection{Autonomy/ Independence}

Actually individuals seek the working opportunity with high level of independence from organization and self_freedom; and they seek jobs that allow flexibility regarding when and how to work.

\subsection{Security/ Stability}

Some people motivated by long-term job security and stability. They do whatever to acquire jab security namely adequate income and stable future. They seek to preserve their attachment to organization.

\subsection{Entrepreneurial Creativity}

Individual with this anchor are mainly motivated by the need to create or to build something to be identified with. They are more interested in setting up new projects; after starting a new project, working in research laboratory, playing an important role in project groups and related activities could be a significant motivation for these individuals.

\subsection{Service/ Dedication to Cause}

People with this anchor pursue work for a higher goal (not merely economical goals) and they largely concern with improving the world, helping society, solving environmental problems and so on.

\subsection{Pure Challenge}


Individuals with this anchor seek to overcome unsolvable obstacles and make a success of difficult situations. They concern with overcoming obstacles, wining out aver tough opponents, solving problems, competition and self-examination.

\subsection{Life Style}

Individuals with this anchor seek a situation that permits the integration of personal needs, family needs and the requirement of the job.

Understanding career orientation is vital for employees, since it enables them to choose the right career anchors. Career anchors recognize the need for a balance between individual career orientations and organization which lead to job satisfaction, high commitment and performance while lack of balance between them leads to dissatisfaction and turnover (Ituma \& Simpson, 2007; Suutari \& Taka, 2007).

The second variable of this study is organizational commitment which will analyze later.

Organizational commitment is a view toward employee's attachment to organization and it is a constant process which indicates the contribution of individuals in organization (Khanifaret et al, 2009). Organizational commitment determines individual identity with a certain organization and his contribution in that organization traditionally organizational commitment considered as a kind of emotional and psychical attachment to the organization. According to this approach individual with strong attachment to this organization, feels united with it and enjoy from being a member of organization (Mooghali et al, 2009). In short being loyal to organization goals' and values and attachment to it called organizational commitment. The research undertaken by Meyer and Allen (1990) identified three aspects of organizational commitment, affective commitment, normative commitment and continuance commitment.

Affective commitment: defined as an affective attachment to organization and its goals. Affective commitment has been conceptualized as employee's emotional feeling of attachment to organization, coincidence with it and engagement within organization. Individuals with strong affective commitment characterized by more attachment to organization because they have greater tendency to be part of the organization.

Normative commitment: normative commitment reflects a set of internalized normative pressure which leads individuals to behave in a manner they believed morally right. Individual with normative commitment is mainly motivated by doing tasks and taking responsibilities. Individuals who are normatively committed to organization are more oriented towards devoting themselves to organization and attempting to achieve its goals.

Continuance commitment: from this perspective the benefits of occupying a particular post and the costs of job leaving have been taken into account. In other words individual with this commitment due to costs of job leaving committed to organization. This view implies that individual attachment to organization is at least as likely to be a result of affection and dependency to organization (e.g. Affective commitment) or normative about tasks duties and responsibility (normative commitment) rather it is merely a response to economical and 
practical consideration (Podaskoff et al, 2000; Rezaian \& keshtgar 2008; Handlon, 2009 and Ghafari \& Golavar, 2010).

\section{Literature Review}

The research into career anchors and its relation with organizational commitment has been subject to limited investigation in Iran and other countries. The aim of this article is to report on an investigation into career anchors and its relation with organizational commitment in Iran. In a study conducted by Hoontan and ChooQuek (Hoontan\&chooQuek, 2001), the authors found a positive and significant relationship between career anchors include technical / functional, autonomy / independence , entrepreneurial creativity , life style ,security/stability ,pure challenge and general managerial competent and employees and external satisfaction

In another study Danzig and Valency (Danzig \& and Valency ,2005) found that was a significant different between career anchors of salaried and self-employment individuals and they suggested that there was a significant relationship between individuals career anchors and job satisfaction The results proved that there is a positive significant relationship between individuals career anchors are as likely to be a result of self-perception, values and occupational motivation (Queensberry, 2006 ). The investigation into career anchors and job signification indicated a positive significant relationship between them (Bester\& Mouton, 2006) in a study of career anchors and organizational commitment Rebecca (2007) found that there is a positive significant relationship between them.

ZakerFard and Nuri (2008) investigated the relationship between career anchors, career vision and organizational commitment. They found that there is a positive significant relationship between them.

In a study of female and male employees occupying in research and development units of industrial firms, Oreyzi and Samvatain et al (2009) found that there was a positive significant relationship between career anchors. Career authority and organizational commitment. BaharFar and Javaheri (2010) in a study of university employees found that there is a positive significant relationship between organizational justice and organizational commitment (affective, normative and continuance commitment). An empirical study investigating career anchors and its behavioral consequences such as organizational commitment is necessary. However, this issue appears to be more important when investigation into career anchors and organizational commitment hold within faculty members.

\section{Hypotheses}

Hypothesis 1: There is a relationship between career anchors and all of aspects of organizational commitment.

Hypothesis 2: There is a relationship between organizational commitment aspects and career anchors.

Hypothesis 3: There is a relationship between career anchors and affective commitment. 
Hypothesis 4: There is a relationship between career anchors and continuance commitment.

Hypothesis 5: There is a relationship between career anchors and normative commitment.

\section{Method}

For the purpose of this study our population consisted of 346 factually members of University of Urmia. The sample size consisted of 70 factually members. Cochran formula was used to determine the sample size (Saraee, 2003)

$$
n=\frac{N t^{2} s^{2}}{N d t^{2}+t^{2} s^{2}}=\frac{346(1.96)^{2}(0.74)^{2}}{346(0.01)^{2}+(1.95)^{2}(0.74)^{2}}=68.82 \cong 70
$$

The data for this study were gathered through two standard questionnaires as outline below:

A-career anchor questionnaire: this questionnaire was based on Schein (1990) career anchor.

B-organizational commitment questionnaire: This questionnaire was based on Meyer and Allen's organizational commitment model (Meyer \&Allen, 1990)

\section{Results}

Analysis of the gathered data shows that:

1-there is a relationship between career anchors and all aspects of organizational commitment aspects.

Table 1. MANOVA analysis of relationship between career anchors and organizational commitment aspects.

\begin{tabular}{|l|l|l|l|l|l|l|}
\hline Career anchors & $\begin{array}{l}\text { Wilkes } \\
\text { Lambda }\end{array}$ & F & $\begin{array}{l}\text { Hypothesis } \\
\text { df }\end{array}$ & Sig & $\begin{array}{l}\text { Partial Eta } \\
\text { Squared }\end{array}$ & $\begin{array}{l}\text { Observed } \\
\text { power }\end{array}$ \\
\hline $\begin{array}{l}\text { Technical/Functional } \\
\text { competence }\end{array}$ & 0.93 & 2.49 & 3 & 0.02 & 0.09 & 0.82 \\
\hline $\begin{array}{l}\text { General/managerial } \\
\text { competence }\end{array}$ & 0.88 & 5.26 & 3 & 0.001 & 0.13 & 0.97 \\
\hline Autonomy/independence & 0.95 & 1.68 & 3 & 0.15 & 0.04 & 0.50 \\
\hline Security/stability & 0.97 & 1.09 & 3 & 0.37 & 0.03 & 0.33 \\
\hline Entrepreneurial Creativity & 0.97 & 1.04 & 3 & 0.41 & 0.02 & 0.32 \\
\hline Service/dedication to a cause & 0.99 & 0.25 & 3 & 0.89 & 0.006 & 0.10 \\
\hline Pure Challenge & 0.95 & 2.02 & 3 & 0.09 & 0.04 & 0.59 \\
\hline Life Style & 0.96 & 1.61 & 3 & 0.14 & 0.04 & 0.48 \\
\hline
\end{tabular}

In table $1 \mathrm{~F}$ coefficients shows that there is a significant relationship between technical competence and all aspects of organizational commitment $(\mathrm{P}=0.02)$ and cooperation rate is $\% 9$. Also there is a significant relationship between general managerial competence and all aspects of organizational commitment $(\mathrm{P}<0.001)$ and cooperation rate is $\% 13$, thus the hypothesis has proved. There isn't a significant relationship between autonomy independence, security - stability, Entrepreneurial creativity, service - dedication to a cause, 


\section{Macrothink}

pure challenge and life style with all aspects of organizational commitment and hypothesis hasn't proved.

2- There is a relationship between organizational commitment aspects and career anchors.

Table 2. MANOVA analysis of relationship between organizational commitment aspects and career anchors

\begin{tabular}{|l|l|l|l|l|l|l|l|}
\hline $\begin{array}{l}\text { Organizational } \\
\text { Commitment aspects }\end{array}$ & $\begin{array}{l}\text { Sum of } \\
\text { Squares }\end{array}$ & $\begin{array}{l}\text { Degree of } \\
\text { freedom }\end{array}$ & $\begin{array}{l}\text { Squares } \\
\text { Mean }\end{array}$ & F & Sig & $\begin{array}{l}\text { Partial Eta } \\
\text { Squared }\end{array}$ & $\begin{array}{l}\text { Observed } \\
\text { power }\end{array}$ \\
\hline Affective commitment & 19.98 & 8 & 2.66 & 3.83 & 0.001 & 0.16 & 0.97 \\
\hline Continuance commitment & 19.00 & 8 & 2.66 & 2.26 & 0.003 & 0.10 & 0.94 \\
\hline Normative commitment & 20.30 & 8 & 2.66 & 4.23 & 0.002 & 0.18 & 0.95 \\
\hline
\end{tabular}

In Table $2 \mathrm{~F}$ coefficients reveals that there is a significant relationship between organizational commitment aspects (affective, continuance, normative commitment) and career anchors $(\mathrm{p}<0.01)$, thus hypothesis 2 has proved in three cases. Cooperation rate between organizational commitment aspects and career anchors is \%16and statistical power \%97 represents that the sample size was adequate. Cooperation rate between continuance commitment aspects and career anchors is $\% 18$ and statistical power $\% 95$ represents that the sample size was adequate.

3- There is a relationship between career anchors and affective commitment

Table 3. multiple regression analysis of relationship between career anchors and affective commitment.

\begin{tabular}{|c|c|c|c|c|c|c|c|c|}
\hline Predictor Variables & Dependent variable & $\mathrm{F}$ & $\mathrm{p}$ & $\mathrm{R}^{1}$ & $\mathrm{R}^{2}$ & $\beta$ & $\mathrm{t}$ & $\mathrm{P}$ \\
\hline Technical/Functional competence & \multirow{8}{*}{ Affective Commitment } & \multirow{8}{*}{3.59} & \multirow{8}{*}{0.001} & \multirow{8}{*}{0.39} & \multirow{8}{*}{0.15} & 0.18 & 2.21 & 0.02 \\
\hline General/managerial competence & & & & & & 0.26 & 3.39 & 0.01 \\
\hline Autonomy/independence & & & & & & 0.006 & 0.06 & 0.94 \\
\hline Security/stability & & & & & & 0.08 & 0.88 & 0.37 \\
\hline Entrepreneurial Creativity & & & & & & 0.09 & 1.02 & 0.30 \\
\hline Service/dedication to a cause & & & & & & 0.02 & 0.24 & 0.80 \\
\hline Pure Challenge & & & & & & 0.14 & 1.53 & 0.12 \\
\hline Life Style & & & & & & 0.19 & 2.38 & 0.01 \\
\hline
\end{tabular}

Table 3 represents that there is a significant relationship between career anchors and affective commitment $(\mathrm{F}=3.59$ and $\mathrm{P}=0.001)$. Thus hypothesis 3 has proved but there is a significant relationship between technical -functional $(\mathrm{P}=0.02)$, general managerial competence $(\mathrm{P}=0.01)$, life style $(\mathrm{P}=0.01)$ and affective commitment.

4- There is a relationship between career anchors and continuance commitment. 


\section{Macrothink}

Table 4. multiple regression analysis of relationship between career anchors and continuance commitment.

\begin{tabular}{|c|c|c|c|c|c|c|c|c|}
\hline Career anchors & Dependent variable & $\mathrm{F}$ & $\mathrm{p}$ & $\mathrm{R}^{1}$ & $\mathrm{R}^{2}$ & $\beta$ & $\mathrm{t}$ & $\mathrm{p}$ \\
\hline $\begin{array}{l}\text { Technical/Functional } \\
\text { competence }\end{array}$ & \multirow{8}{*}{$\begin{array}{l}\text { Continuance } \\
\text { commitment }\end{array}$} & \multirow{8}{*}{4.19} & \multirow{8}{*}{0.0001} & \multirow{8}{*}{0.41} & \multirow{8}{*}{0.17} & 0.23 & 2.90 & 0.004 \\
\hline $\begin{array}{l}\text { General/managerial } \\
\text { competence }\end{array}$ & & & & & & 0.28 & 3.67 & 0.001 \\
\hline Autonomy/independence & & & & & & 0.17 & 2.01 & 0.04 \\
\hline Security/stability & & & & & & 0.06 & 0.65 & 0.51 \\
\hline Entrepreneurial Creativity & & & & & & 0.15 & 1.77 & 0.07 \\
\hline Service/dedication to a cause & & & & & & 0.05 & 0.61 & 0.53 \\
\hline Pure Challenge & & & & & & 0.18 & 1.93 & 0.04 \\
\hline Life Style & & & & & & 0.13 & 1.56 & 0.09 \\
\hline
\end{tabular}

Table 4 represents that there is a significant relationship between career anchors and continuance commitment $(\mathrm{F}=4.19, \mathrm{P}=0.0001)$. Thus hypothesis 4 has proved but there is significant predictor relationship between technical/ functional competence $(\mathrm{P}=0.004)$, general managerial competence $(\mathrm{P}=0.001)$, autonomy - independence $(\mathrm{P}=0.04)$, pure challenge $(\mathrm{P}=0.04)$ and continuance commitment.

5- There is a relationship between career anchors and normative commitment.

Table 5.

\begin{tabular}{|c|c|c|c|c|c|c|c|c|}
\hline Career anchors & Dependent variable & $\mathrm{F}$ & $\mathrm{p}$ & $\mathrm{R}^{1}$ & $\mathrm{R}^{2}$ & $\beta$ & $\mathrm{t}$ & $\mathrm{p}$ \\
\hline Technical/Functional competence & \multirow{8}{*}{$\begin{array}{l}\text { Normative } \\
\text { commitment }\end{array}$} & \multirow{8}{*}{3.70} & \multirow{8}{*}{0.001} & \multirow{8}{*}{0.39} & \multirow{8}{*}{0.15} & 0.20 & 2.51 & 0.01 \\
\hline General/managerial competence & & & & & & 0.32 & 4.07 & 0.001 \\
\hline Autonomy/independence & & & & & & 0.04 & 0.56 & 0.57 \\
\hline Security/stability & & & & & & 0.01 & 0.18 & 0.85 \\
\hline Entrepreneurial Creativity & & & & & & 0.15 & 1.75 & 0.08 \\
\hline Service/dedication to a cause & & & & & & 0.08 & 0.09 & 0.92 \\
\hline Pure Challenge & & & & & & 0.09 & 0.96 & 0.33 \\
\hline Life Style & & & & & & 0.08 & 1.02 & 0.30 \\
\hline
\end{tabular}

Table 5 represents that there is a significant relationship between career anchors and normative commitment $(\mathrm{F}=3.70$ and $\mathrm{P}=0.001)$. Thus hypothesis 5 has proved but there is a significant predictor relationship between technical functional competence $(\mathrm{P}=0.01)$, general managerial competence $(\mathrm{P}=0.001)$ and normative commitment.

\section{Discussion}

It is obvious from the findings that there is a positive significant relationship between career 
anchors and organizational commitment. Thus each organization should pay much more attention to career anchors and organizational commitment.

Thus each organization should pay much more attention to career anchors, especially when organization needs to asses the strengths and weaknesses of its human forces Career anchor is a pattern of self-perceived talents, motives and values that serve to guide, constrain, stabilize and integrate individual careers.

Although it could be argued that the difference in career anchors is a predicator of the likelihood of career advancement. Improving our understanding of these nonmonetary motivators for careers are likely to be essential in determining effective approaches to career development in the future. Career anchors emerged as a way of explaining the pattern of reasons of why individuals progressed through their careers.

They serve to explain how and why an individual interacts with the organization career anchors effect work and career satisfaction and career orientations provide a way of understanding these motivators of career decisions.

Analyzing the individual career anchors help the organization to redesign the careers in response to individuals needs and also outline the career changes. In recent years researchers

Have studied the relationship between career anchors and behavioral consequences such as organizational commitment.

In this study suggests that there is a positive significant relationship between career anchors and organizational commitment. Satisfied staff is a crucial factor in every organization, not only leads to enhance performance and decrease absence rate, delay and job left but also permits the integration of personal needs. Organization needs and the requirement of the job. instead dissatisfied staff not only won't consider the organization needs but by creating an inattentive cultures toward organization's issues and problems may weaken other staff morale and eventually may delay or hinder the organization prosperity. The gathered data were analyzed according to hypotheses.

Table 1 presents the relationship between career anchors and all aspects of organizational commitment. it indicate that there is a positive significant relationship between technical functional competence, general managerial competence and all aspects of organizational commitment, but there isn't a significant relationship between autonomy - independence, security - stability, Entrepreneurial creativity, service - dedication to a cause, pure challenge and life style the finding of this hypothesis supports other studies (Oreyzi Samani et al, 2009; Zakerfard and Vuri, 2008; Rebecca, 2007)

Table 2 presents the relationship between organizational commitment aspects and career anchors. it indicates that there is a positive significant relationship between organizational commitment aspects (affective, continuance. normative) and career anchors. The findings of this hypothesis support the research results (Oreyzi and Samani et al, 2009)

Table 3 presents the relationship between career anchors and effective commitment. it reveals that there is a positive significant relationship between career anchors and affective 
commitment (Fs 3.9 , Ps 0.0001).

Among career anchors technical - functional competence (ps 0.02), general managerial competence (ps 0.01) and life style (ps 0.01) have a significant predictor relationship with affective commitment. The findings of this hypothesis support the research results (Oreyzi Samani et al, 2009)

Table 4 presents the relationship between career anchors and continuance commitment. The finding suggested that there is a positive significant relationship between career anchors and continuance commitment (ps 4.19, ps 0.0001) among career anchors technical - functional competency (Ps 0.004), general managerial competency (Ps 0.001), autonomy-independence $(p=0.04)$ and pure challenge $(p=0.04)$ have a significant predictor relationship with continuance commitment. Findings of this hypothesis support the research results (Oreyzi Samani et al, 2009).

Table 5 presents the relationship between career anchors and normative commitment. The results suggested that there is a positive significant relationship between career anchors and normative commitment (Fs 3.70, $\mathrm{p}=0.001$ ). Among career anchors only technical functional competence $(p=0.01)$ and general managerial competence $(p=0.001)$ have a significant predictor relationship with normative commitment. Findings el this hypothesis supports the research results (Oreyzi Samani et al, 2009) indicates that this study faculty members showed a greater likelihood of having a technical-functional, general managerial competency, autonomy- independence and pure challenge anchors. Researches believe that if individuals with technical - functional anchors have an opportunity to apply their technical skills, also those with general managerial anchors being responsible for the output of a particular unit of the organization, and individuals with pure challenge anchor have the opportunity to work on solutions to seemingly unsolvable problems, they will be more Satisfied and have higher level of organizational commitment. So organization can achieve its goals.

\section{References}

Abbaspour, A. (2008). Advanced human resource management, (Approaches, Process and Functions), Tehran: Samt Publication (In Persian).

Ashwin, P. (2006). Changing higher education, First Published, Rout ledge: Taylor Francisco Group.

BaharFard, A., \& Javaheri, M. (2010). The study of organization ethical values consequences (The study of organization equality, organization commitment and organization citizenship behavior), Bimanthly Police Human Development, Vol.7, No.28, pp.25-118 (In Persian).

Bakhtiyar Nasrabadi, H., Rajaeepour, S., Salimi, G.A., \& Taherpour, F.and Partoui, M. (2009). Relation between the job content and job satisfaction. Isfahan Iran Mill Co. staff members. Journal of Executive Managemen, Vol.9, No.33,pp. 57-67 (In Persian).

Bester, G.L, \& Mouton, T. (2006). Differences regarding job satisfaction and job involvement of psychologists with different dominant career anchors. Journal of 
Management Development, Vol 29, No. 3, pp. 50-55.

Danziger, N., \& Valancy, R. (2005). Career anchors distribution and impact on job satisfaction, the Engeland case. Career Development International, Vol.11, No. 4, pp. 293-303. http://dx.doi.org/10.1108/13620430610672513

Danziger, N., Moore, D., \& Valancy, R. (2008). The construct validity of Schien's career anchors orientation inventory. Career Development International, Vol.3, No.1, pp. 7-19. http://dx.doi.org/10.1108/13620430810849506

Galavandi „H., Rajaeepour ,S., Molavi, H., \& Sharif, S.M. (2010). Astudy of the relationship between quality of work like and career anchors with organizational performance perspective among faculty members of the Universities. Journal of Psychology, Vol. 5, No. 19, pp.113-134.

Galavandi, H. (2010). Determination of relationship between quality of work life and career anchors with organizational performance perspective of faculty members in Tabriz, Urmia and Ardabil Universities, Ph.D. Dissertation, university of Isfahen (In Persian).

Ghafouri, M. R., \& Golparvar, M. (2010). A survey of relationship between organization justice with organizational commitment among staff of Isfahan Municipality. Psychological Studies, Vol.5, No.4, pp.129-148 (In Persian).

Handlon, R.L. (2009). The departure of the insurance agent: The impact organizational commitment, organizational justice, and job satisfaction have an intent to leave in the insurance industry, Ph.D. Dissertation, Capalla University.

Hoon Lee, S., \& Wong, P.K (2004). An exploratory study of technopreneurial Intentions: a career anchor perspective. Journal of Business Venturing 19, 7-28. http://dx.doi.org/10.1016/S0883-9026(02)00112-X

Hoon Tan, H., \& Choo Quek, B.C (2001). An exploratory study on the career anchors of educators in Singapore. The Journal of Psychology, Vol.135, No. 5, pp. 527-545. http://dx.doi.org/10.1080/00223980109603717

Ituma, A., \& Simpson, R. (2007) Moving beyond Schein's typology individual career anchors in the content of Nigeria. Personal Review, Vol.36, No.6, pp. 978-995. http://dx.doi.org/10.1108/00483480710822463

Jiang, J.; Kllein, G., \& Balloun, J. L. (2001). The joint impact of internal and external career anchors on entry- level IS career satisfaction. Information \& Management 39, 31-39. http://dx.doi.org/10.1016/S0378-7206(01)00077-5

Keshtegar, A.A., \& Rezain, A. (2008). The relationship between emotional intelligence and organizational commitment. Management Perspective, Vol. 8, No. 27, pp.27-40.

Khanifar, H; Moghimi, S.M.; Jandaghi, G. R., \& Zarvandy, N. (2009) Analysis of relation between elements of trust and organizational commitment of personnel. Journal Public Administration, Vol.1, No.1, pp.3-18 (In Persian). 
Lick, D.W. (2002). Leadership and change, in field guide to academic leadership, San Francisco, Josses Bass.

Meyer, J.P., \& Allen, N.J. (1990). A three-component conceptualization of otganization of organizational commitment. Human Resource Management Review, Vol.1, pp. 61-89. http://dx.doi.org/10.1016/1053-4822(91)90011-Z

Mir Kamali, S.M. (2004). Foundation of human resource management, Tehran, Yastaroon Publications (In Persian).

Mooghali, A.R., Hassanpour, A., \& Hassanpour, M. (2009). Surveying of the relationship between employee empowerment and organizational commitment in the 19 District of Tehran education organization. Journal Public Administration. Vol.1, No.1, pp.119-132 (In Persian).

Oreyzi Samani, H.R, Zakerfard, M., \& Nuri, A. (2009). The relationship of career with job power and organizational commitment: A case study of male and female personal of research and development units of industrial companies, Woman's Studies Sociological and Psychological. Vol.7, No.1, pp.69-93 (In Persian)

Pelos, S. G. (2000). Career orientations of female entrepreneurs: a study using Schein's career anchor theory, Ph.D. Dissertation, University of San Francisco

Podsakoff, P.M., Makenzie, S.B., \& Paine, J.B. (2000). Organizational citizenship behaviors: A critical review of the theoretical and empirical literature and suggestions for future research. Journal of Management, Vol. 26, pp.513-533. http://dx.doi.org/10.1177/014920630002600307

Quesenberry, J.L. (2006). Career anchors and organizational culture: A study of woman in the IT workforce Sigmis cporb proceeding of the ACM Sigmis Cpr conferences, pp. 342-344.

Rebecca, T. (2007). The relationship between career anchors and organizational commitment, M.A. Dissertation, University of South Africa.

Romphel, G. (2006). Constructing knowledge societies: New challenges for tertiary education, translators: mokhtaripour et al, Esfahan University Publication.

Saraee, H. (2003). An introduction to sampling in research, Vol.3, Tehran: Samt Publication (In Persian).

Sardari, A. (2002). Job satisfaction in organization. Scientific Research Journal of Shahed University, Ninth Year, No. 39, pp.67-88(In Persian).

Schein, E.H. (1990). Career anchors: Discovering your real values, San Francisco: Jossey Bass Pfeiffer. http://dx.doi.org/10.1108/03090590410549984

Schein, E.H. (1996). Career anchors revisited implications for career development in the $21^{\text {st }}$ Century, Academy of Management Executive, Vol.10, No. 4, pp. 80-88.

Smith, D. L. (2005). The relationship between career anchors and a team's ability to meet organizational goals: a case study, Ph.D. Dissertation, Capella University. 


\section{Macrothink}

Suutari, V., \& Taka, M. (2007). Career anchors of managers with global careers, Journal of Management Development, Vol.23, No.9, pp. 899-912. http://dx.doi.org/10.1108/02621710410558440

Vanneste, J. M. (2005). Schein's career anchor model and its relevance to career satisfaction: a case study of engineers at micro motors, Ph.D. Dissertation, Capella University.

Verbruggen, M., Sels, L., \& Forrier,A. (2007). Unraveling the relationship between organizational career management and the need for external career counseling. Journal of Vocational Behavior 71, pp. 69-83. http://dx.doi.org/10.1016/j.jvb.2007.03.003

Zaker Fard, M. S., \& Nuri, A. G. (2008). Relation between career and Organizational commitment, The First Crenation Industrial and Organizational Psychology, University of Esfahan. 